\title{
Development of expressive writing program : Psychosocial intervention for cancer patients
}

\author{
표현적 글쓰기 프로그램 개발 : 암 환자의 심리사회적 간호중재
}

Nursing Science Department, Gachon University of Medicine and Science

Eun Young Park

가천의과학대학교 간호학과 박은영

\section{서 론}

암 치료의 눈부신 발전에도 불구하고 암은 아직까지 생명을 위협 하는 질병으로 받아들이고 있다. 그렇기에 많은 암 환자들은 암 을 진단받은 사건을 죽음을 연상하는 외상으로 받아들이고 있으 며, 이에 따라 불안과 우울, 또는 심한 감정적 혼란을 경험하게 된다(이명선, 김종흔, 박은영, 김종남, 유은승, 2010; Pedersen \& Zachariae, 2009). Pedersen과 Zachariae (2009)의 보고에 의하면, 암 진단 후 $34.8 \%$ 의 대상자가 급성 스트레스 장애의 범 주에 있고, 특히 여자가 남자보다 두 배 많은 증상을 보이고 있 다. 이러한 결과는 장기 암 생존자들에게서 암 진단 후 외상 후 스트레스 증후군과 유사한 증상이 나타난다는 보고(김희정, 권정 혜, 김종남, 이란, 이건숙, 2008; Mystakidou, et al., 2008)를 통해서도 암 진단이 스트레스 사건임을 보여주고 있다.

Lazarus(1999)는 과도한 자극에 적응하는 개인의 생리적, 심리 적, 행태적 반응을 스트레스(stress)라고 정의하며, 스트레스로 인해 나타나는 스트레스 반응은 개인적 또는 환경적 중개요인의 영향을 받는다고 주장한다. 이러한 영향력 있는 중개요인 중 스 트레스 과정에서 감정이 가장 핵심적인 요인으로 감정이 갖는 영 향력을 강조하면서 스트레스 경험을 감정적 탈진(emotional exhaustion)의 한 형태로 설명하고 있다. 예컨대 사람들은 스트 레스를 경험하면 감정의 변화를 보이고 이러한 감정의 변화는 신 경생리학적인 변화를 동반함으로써 신체 · 정신 건강에 영향을 미친다. 특히 스트레스 사건으로 유발된 부정적 정서는 건강에

\section{책임저자 : 박은영}

406-799, 인천 연수구 연수3동 534-2 가천의과학대학교 간호학과 Tel: 0032-820-4207 Fax: 032-820-4201 E-mail: parkeunyoung@gachon.ac.kr 접수일 : 2011년 5월 23일 ; 게재승인일 : 2011년 6월 20일
해로운 영향을 미칠 가능성이 높다(전겸구, 김동현, 2000 ; Lazarus, 1999). 이러한 견해는 암 환자의 삶의 질에 영향을 미 치는 가장 주요한 요인으로 암 진단 시 스트레스 정도를 제시하 고 있으며, 암 관련 스트레스가 암 환자의 치료과정과 그 이후의 심리적 삶의 질에 큰 영향을 준다는 Golden-Kreutz 등(2005)의 보고와 일치한다.

암으로 인한 스트레스에 대해 Temoshok(1995)는 개인의 스트레 스 대처기술이 부족하거나 지나치게 과도하면 암 관련 스트레스 를 해결하지 못하게 되며, 해결되지 못한 스트레스는 면역력을 감소시켜 신체증상으로 발현되고 대인관계가 무너지고 사회적으 로 고립되는 결과를 가져온다고 주장한다. 그렇지만, 암 관련 스 트레스에 대한 부정적 감정을 표현할 수 있는 적절한 심리사회 중재가 제공되면 면역력과 사회적 지지가 증진되어 암 치료결과 에 긍정적 영향을 주게 됨을 강조하였다. 이러한 암 관련 스트레 스에는 암 환자가 자신의 슬픔과 억울함, 그리고 분노와 같은 감 정을 제대로 표현하지 못하는 것이 하나의 커다란 요인으로 작용 하고 있다(김은심, 이민규, 최지명, 2006; 배선희, 2009; Spiegel, \& Giese-Davis, 2003). 실제적으로 암을 진단받고 치 료 중인 환자와 치료가 끝난 생존자들 모두가 암과 관련된 자신 의 감정을 제대로 표현하지 못하는 것으로 알려져 있다(배선희, 2009; Ho, Chan, \& Hol, 2004; Spiegel, \& Giese-Davis, 2003). 암 관련 스트레스는 암 환자들에게 암 진단과 함께 죽음 을 연상시키고, 부정과 불안, 그리고 분노를 유발시킨다. 이 분노 가 적절히 표현되지 못하고 내면에 축적되면서 우울이 초래되고 자살을 생각하기도 한다(Grassi, \& Travado, 2008).

불안, 우울과 같은 암 환자의 심리증상은 암의 진행 과정과 그 결 과에 영향을 주는 주요한 요인이며 이와 관련한 감정표현 정도와 정적 상관관계를 갖고 있다(서경현, 김명석, 2003). 따라서 부적 
절한 감정표현은 결과적으로 암 환자의 우울에 심각한 영향을 미 치므로 암 환자의 부정적 감정을 효율적으로 조절하고 관리할 수 있는 간호중재가 필요하다(이평숙, 손정남, 이용미, 박은영, 박지 선, 2005; Iwamitu, et al., 2005). 그렇지만 암 환자가 감정을 표현하는 데에는 여러 요인의 영향을 받는다. 상반된 감정에 의 한 충동성과 분노표출 욕구를 억제하려는 행동(Servaes, Vingerhoets, \& Vreuhderhil, 1999)과 자신들의 감정표현이 수 용되지 못한다는 인식(Zakowski, Ramati, Morton, \& Jphnson, 2004), 그리고 부정적 감정의 표현을 자제하도록 하는 문화적 관습(배선희, 2009; $\mathrm{Ho}, \mathrm{Chan}, \& \mathrm{Hol}, 2004$ )과 직접적 인 표현으로 의사소통 하는 것이 수용되기 어려운 사회적 맥락 (Iwamitsu, et al., 2005)등 개인과 사회적 차원의 다양하고 복잡 한 요인들이 암 환자로 하여금 암과 관련한 부정적 감정을 표현 하는 것에 어려움을 주고 있다.

최근 들어 이러한 맥락에서 암 환자를 대상으로 미술, 음악, 무용 등 다양한 방법의 중재가 적용되고 있으며 그 결과 암 환자의 심 리 증상이 완화되고 삶의 질에 긍정적 영향을 주고 있는 것으로 나타나고 있다. 반면 예술기법을 통한 암 환자의 감정표현 중재 는 많은 경우에 정서적 정화(catharsis) 효과가 대부분이고 그 내 용과 기제에 대한 검증이 부족해 효과에 대한 의문이 계속되고 있다(Olofsson, \& Fossum, 2009).

암 환자의 불안, 우울과 같은 심리증상에 대한 중재로 우리나라 임상에서 가장 많이 제공되는 것은 교육과 정보제공의 심리교육 중재가 대부분이다(김종남, 이란, 2008). 이러한 심리교육 중재는 암 환자 내면의 암 관련 감정의 표현보다 심리지지와 정보제공에 중점을 두고 있어 암 진단과 치료에 따른 환자 내면의 정서적 격 분을 해결하기보다는 암으로 인한 심한 정서적, 신체적 스트레스 상황에 효과적으로 대처할 수 있는 환경과 자원 제공의 중재이다. 그렇지만 암을 스트레스 사건으로 경험하는 환자들의 신체적, 심 리적 안녕을 증진시키기 위해서는 효과적 대처를 위한 지지보다 는 암 환자가 그 사건에 대한 내적 해석과 감정 표현을 격려하는 것이 매우 중요하다(원호택, 1997; Stanton, et al., 2000).

암 관련 스트레스를 적절히 해결하기 위해 암 환자에게 필요한 심리중재는 암 관련 스트레스에 관한 내적해석과 감정표현을 위 한 방법이 더욱 중요하며 이를 위한 효과적인 중재 방법으로 2000년 이후 언어를 통한 감정 표현이 제시되고 있다(Rancour \& Brauer 2003; Smith, et al., 2005; Stanton et al., 2000; Zakowski, et al., 2004). 언어를 통한 감정 표현 방식에는 말과 글이 있으며 이들의 심리적 치료 효과는 동일하다고 알려져 있다
(Lange, et al., 2003). 글을 통한 감정 표현 중재 중에서는 표현 적 글쓰기가 특히 효과적인 것으로 보고되고 있는데, 그 이유는 스트레스 사건에 대한 깊은 생각과 감정을 반복적으로 글로 표현 함으로써 스트레스 사건에 대한 부정적 감정표현을 증가시켜 정 서조절 능력을 향상시키고, 그 사건에 대해 회피하고 싶은 침투 적 사고를 변화시켜 그 사건에 직면하게 하여 그에 대한 인지를 재구조화 시킬 수 있기 때문이다(Davidson, et al., 2003; Pennebaker, 1997).

2000년 이후 외국에서는 표현적 글쓰기가 암 환자에게 효과적인 것으로 보고되고 있지만, 국내에서는 외상후 스트레스 증후군의 일부에서 적용했을 뿐 암 환자의 감정 표현을 목적으로 한 표현 적 글쓰기는 시도되지 않고 있다. 따라서 암 환자를 대상으로 암 과 관련된 생각과 감정을 효과적으로 표현하도록 돕는 표현적 글 쓰기 프로그램을 간호중재로 개발하여 그 효과를 검증하는 연구 가 필요하다. 이에 본 연구는 유방암 환자를 위한 표현적 글쓰기 프로그램을 개발하고 적용가능성을 검증하고자 한다.

\section{표현적 글쓰기 프로그램}

\section{1. 치료적 기제}

Pennebaker(2004)는 표현적 글쓰기란 스트레스 사건에 대한 깊 은 생각과 감정에 대한 반복적 글쓰기로 정의하였다. 사람들은 자신의 생각과 감정을 탐색하고 언어로 표현함으로써 인식, 통 찰, 이해로 나아간다. 이러한 현상은 반복적인 표현적 글쓰기가 감정과 인식으로 하여금 그 사건에 익숙하게 만드는 둔감화 이론 (habituation)으로도 설명한다. 또한 표현적 글쓰기 과정에서 대 상자에게 일어나는 일련의 과정을 1) 즉각적인 인지 변화, 2) 즉 각적인 감정 변화, 3) 장기적인 감정과 인지 변화, 4) 사회적 관계 개선, 5) 생리적 효과의 5 가지로 제시하면서 이러한 과정이 복합 적이고 다차원적으로 대상자에게 작용한다고 설명한다.

Davidson 등(2003)은 침투적 사고 변화와 감정조절을 매개로 한 표현적 글쓰기의 치료기제에 대해 다음과 같이 제시하였다(Fig. 1).

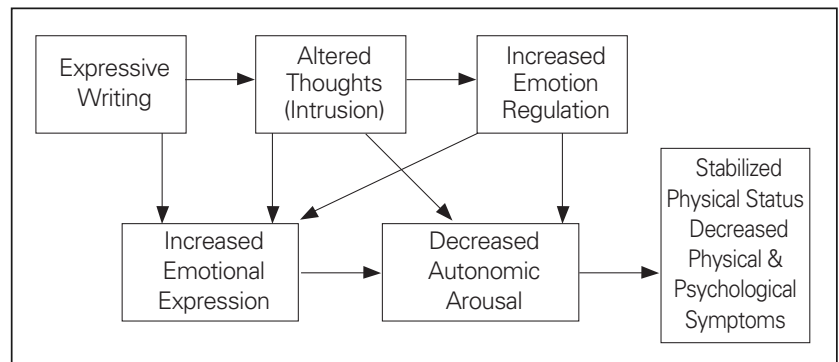

Fig. 1. Therapeutic mechanism for expressive writing (Davidson, et al., 2003) 


\section{2. 암 환자에서의 효과}

최근 들어 발표되고 있는 암 환자의 표현적 글쓰기 중재의 치료효 과에는 신체적 증상과 병원 방문횟수의 감소가 대부분의 연구에서 유의하게 보고되고 있다(Smith, et al, 2005: Stanton, et al., 2002). 유방암 환자를 대상으로 한 표현적 글쓰기 중재 연구결과에 서는 신체증상의 완화와 Cortisol level 감소, 그리고 삶의 질 향상 등의 효과가 보고되고 있다(Laccetti, 2007; Stanton, et al., 2002). 또한 유방 절제술과 복원술의 과정 동안 편지쓰기를 실시한 연구에서는 변화하는 신체상에 대한 수용과 효과적인 대처과정이 나타났으며(Rancour \& Brauer, 2003) Zakowski, 등(2004)은 표 현적 글쓰기가 사회적 규제의 스트레스에 대한 완충작용 효과가 있 음을 보고했다.

암 환자에게 표현적 글쓰기를 제공할 때 나타나는 효과들의 치료기 제에 대한 다수의 연구의 결과는 기존의 표현적 글쓰기가 갖는 침 투적 사고의 영향과 감정조절 기제 등이 암 환자에게서도 동일하게 나타나고 있음을 보여주고 있다.

\section{암 환자의 표현적 글쓰기 프로그램 개발}

\section{1. 프로그램의 초기 적용 및 결과}

Pennebaker (2004/2007)의 워크북에 제시된 표현적 글쓰기 프로 그램을 토대로, 그룹 작업으로 편성하였으며 주1회 4회기로 구성하 였다. 각 회기의 글쓰기 시간을 20-30분으로 배정하였으며 프로그 램이 구조화되어 있지 않은 Pennebaker의 표현적 글쓰기에 도입 - 글쓰기 - 종결의 3단계의 구조화를 접목하였다. 도입단계에서는 Pennebaker가 제시한 글쓰기 준비와 총칙에 준하여 선행연구에 서 추출된 암 환자의 공통된 부정적 정서반응에 관한 글쓰기의 주 제와 지침을 설명하였다. 실행단계에서는 20 분 동안 자신이 선택 한 주제에 대해 Pennebaker의 표현적 글쓰기 지침에 준하여 글쓰 기를 하였고, 종결단계에서는 글에 표현된 감정표현 정도와 감정 표현 이후의 지금의 심정에 중점을 두고 나누도록 하였다.

2009년 8월부터 10월까지 서울시 소재 종합병원 암센터에서 글쓰 기로 내마음 치유하기'라는 이름으로 프로그램을 운영하였다. 총 12 명의 암 환자가 참여하였으며 10 명이 여성 암 환자였다. 질환별 로는 유방암 환자 5 명, 대장암 환자 3 명, 폐암 2 명 후복막 암 1 명, 보호자 1명이었다. 참여자에게 프로그램 시작 전에 한국판 감정표 현 불능지수 척도(신현균, 원호택, 1997)로 감정표현 불능 정도를 측정한 결과 참여자들의 감정표현 점수는 평균 62.5 점으로 강상건 (2002)의 기능성 소화불량증 환자와 일반인의 점수보다 높아 평상 시 감정표현이 어려운 것을 알 수 있었다. 그리고 글쓰기 첫 회기
후 측정한 글에 나타난 감정표현 정도는 7.2점, 글 쓴 후 행복감 정 도는 7점, 슬픔과 우울 정도는 3.3점, 글쓰기의 의미와 가치 점수는 8.1점으로 조선희, 하양숙(2006)의 알코올 의존자 가족을 대상으로 첫 번째 글쓰기를 시행한 후 측정한 점수와 유사하여 암 환자들이 표현적 글쓰기 프로그램에 잘 적응하는 것을 알 수 있었으며, 암 환 자에게 표현적 글쓰기 프로그램이 감정표현을 격려하는 효과적인 중재이며, 적용가능성도 확인되었다.

프로그램의 초기 적용을 통해 암 환자의 표현적 글쓰기 프로그램의 내용과 구성에 대한 수정과 보완점으로 다음과 같은 결론을 얻었다. 첫째, 표현적 글쓰기 프로그램의 목적, 형식, 기간에 대한 정확하고 충분한 안내가 필요하다.

둘째, 글쓰기 전 후의 심리적 간호중재가 필요하다. 암과 치료에 따 른 복합적인 간호문제에 대한 지지적 간호 제공이 프로그램 내에 포함되는 것이 필요하였다.

셋째, 치료과정, 성별에 대한 대상자 선정에 대한 고려가 필요하다. 항암화학요법 치료중인 참여자는 글쓰기보다 현재 치료와 관련된 정보와 자신이 겪고 있는 부작용에 대한 다른 참여자들의 경험을 듣기 원하였다.

넷째, 자유로운 글쓰기 주제 선정이 필요하다. 연구자가 준비하여 제시한 글쓰기 주제 목록이 참여자의 글쓰기 주제를 제한하기도 하 였다.

\section{2. 프로그램의 목적과 목표}

암 환자의 표현적 글쓰기 프로그램은 Pennebaker(2004/2007)의 표현적 글쓰기와 초기 적용 결과, 연구자의 표현적 글쓰기 참여 경 험, 그리고 Adams(1998/2006)와 채연숙(2010)의 글쓰기 치료의 실제 워크북을 토대로 구성하였다.

암 환자의 표현적 글쓰기 프로그램은 〈마음쓰기 교실〉의 이름으로 진행하였다.

본 프로그램의 목적은 암 환자들의 암 관련 생각과 감정을 글로 표 현하도록 하여 감정을 언어로 표현할 때 나타나는 감정조절과 인지 변화의 치료기제의 도움으로 삶의 질이 향상되는 것이다.

본 프로그램의 구체적 목표는 다음과 같다.

첫째, 암 진단과 치료에 따른 내재된 자신의 암 관련 생각과 감정을 찾는다.

둘째, 암 진단과 치료에 따른 내재된 자신의 암 관련 생각과 감정을 인식한다.

셋째, 찾아진 암 관련 생각과 감정에 직면하고 이를 인정한다.

넷째, 찾아진 암 관련 생각과 감정을 글로 표현한다. 
이상의 목표를 달성하기위한 전략으로 6 회기 전 과정 동안 매 회기 프로그램의 구성에 따라 진행되는 활동에 적극적으로 참여하며, 표 현적 글쓰기 지침에 따라 성실히 글쓰기에 임하여 매 회기마다 암 관련 생각과 감정을 효과적으로 표현한다.

\section{3. 프로그램의 구조}

본 프로그램은 주 1 회씩 총 6 회, 1 회 1 시간 30 분으로 진행되며, 기 본 구조는 채연숙(2010)의 제시한 글쓰기 치료의 단계를 참조하여 도입단계 - 마음준비 단계 - 글쓰기 단계 - 자기 성찰단계 - 나눔 과 계획 단계의 5 단계로 구성되어 있다. 도입단계에서는 집단 역동 성 강화와 상호 신뢰 만들기, 마음열기를 달성하고 마음준비 단계 에서는 프로그램 목표에 따른 암 관련 생각과 감정을 찾고 인식하 며, 글쓰기 단계에서는 인식된 생각과 감정을 인정하고 집중적으로 글로 표현한다. 자기성찰 단계에서는 글쓰기로 인한 생각과 감정의 변화를 관찰하고 나눔과 계획 단계에서는 상호 피드백을 통해 감정 을 나누고 상호 지지하여 생각과 감정표현의 즉시효과를 갖도록 계 획하였다. 6 회기 전체 흐름을 통해서도 회기의 진행에 따라 각 단 계의 정도가 깊어지도록 구성하여 암 환자의 표현적 글쓰기 프로그 램을 제시하고자 한다. 본 프로그램은 교육프로그램과 달리 회기의 진행에 따라 목표와 이에 따른 활동의 변화는 없지만, 다양한 방법 을 통해 암 관련 생각과 감정을 연상시키고 자극시킬 필요가 있어 (Pennebaker, 2004/2007) 마음준비단계의 활동은 매 회기 다르 게 구성하였다.

(1) 도입단계에서는 집단 역동성 강화와 상호 신뢰 만들기, 마음열 기를 목적으로 자기소개, 지난 한 주일 생활 이야기 나누기, 프로그 램에 대한 기대 나누기 등의 활동을 한다. 이 단계는 매 회기 거의 유사하게 구성되었다.

(2) 마음준비단계에서는 암 관련 생각과 감정을 찾고 인식하기 위 한 목적으로 다양한 작업(그림 감상, 노래 듣기, 빠른 글쓰기, 자화 상 그리기, 시집 읽기, 몸 명상, 편지쓰기)으로 구성하였다. 이 단계 에서는 매 회기마다 다른 활동으로 준비하였으며 모든 활동은 암 관련 깊은 생각과 감정을 이끌어 낼 수 있는 소재로 이루어졌다. 글 쓰기의 주제에 대한 주제 목록을 제시하지 않고 참여자 스스로 암 관련 생각과 감정을 이끌어 낸 후 자유롭게 선택하도록 하였다. 이 단계의 활동을 통해 연상된 암 관련 생각과 감정을 마음으로 정리 하도록 진행하였다.
(3) 글쓰기 단계에서는 인식된 생각과 감정을 인정하고 집중적으로 글로 표현하는 것을 목적으로 선택한 주제에 대해 표현적 글쓰기 지침에 따라 20 분 이상 쉬지 않고 글쓰기를 한다. 개인별 글쓰기가 종료되는 대로 글쓴 후 소감을 정리하였다.

(4) 자기성찰단계에서는 자기 통찰을 목적으로 자신이 쓴 글을 다 시 읽어보면서 자신의 감정과 생각을 객관적으로 평가하고 자신의 감정 상태와 감정 표현 이후의 변화를 성찰하기 위한 단계이다.

(5) 나눔과 계획 단계에서는 자기 체험 강화 및 정체성 강화, 새로운 나의 모습과 삶의 틀 만들어 가기를 목적으로 최종 느낌 나누기, 글 쓴 후 소감 나누기, 상대방에게 긍정적 공감 및 활력 강화하기, 일 주일 생활 계획 발표 등을 시행하였다. 참여자들이 쓴 글의 내용에 대해서는 Pennebaker의 지침에 따라 어떠한 피드백도 제공하지 않았으며 감정표현을 어려워하는 참여자에게는 개별적으로 구체적 인 표현 방법에 대한 가이드를 지공하였다.

프로그램 운영을 위한 준비로는 참여자가 8명이 넘지 않도록 배정 하였으며, 전 과정에 명상음악을 제공하여 환경적 조성을 준비하고 프로그램 진행 장소는 원탁으로 좌석을 배치하여 모든 참여자가 동 등한 자기 위치를 가질 수 있도록 하였다. 또한 본 프로그램을 위해 워크북을 제작하여 사용하였다. 프로그램의 구성내용은 Table 1.에 제시하였다.

\section{결 론}

우리나라 암 환자들은 감정을 드러내지 않는 것이 미덕인 문화적 관습과 '몹쓸 병' 이라고 인식되는 암에 대한 사회적 낙인 때문에 암을 진단받는 그 순간부터 암으로 인해 파생되는 복잡한 감정을 표현하지 못하는 경우가 많다. 특히 여성 암 환자의 경우 그 정도가 더욱 심각하여 암 진단 이후 인간관계의 단절, 가족관계의 어려움 등을 호소하는 이들이 적지 않다. 많은 사람들이 이미 주지하는바 와 같이 암은 진단받은 당사자에게는 인생의 큰 스트레스 사건임에 분명하다.

암 환자를 위한 표현적 글쓰기 프로그램 〈마음쓰기 교실〉은 이러한 암 환자의 암 관련 스트레스를 글을 통해 언어가 갖는 인지적, 정서 적 치유효과를 적용하기 위해 개발하였다. 표현적 글쓰기 프로그 램에서 가장 중요한 요소는 효과적으로 표현적 글쓰기를 가능하도 록 하는 방안이다. Pennebaker(2004/2007)가 설명한대로 표현적 글쓰기를 통한 치료적 효과를 극대화하기 위해서는 다양한 보조적 
Table 1. Contents of expressive writing program

\begin{tabular}{|c|c|c|c|c|}
\hline \multirow{2}{*}{ Purpose } & \multicolumn{4}{|c|}{ Attention to self arousal of cancer-related deep thoughts and emotion } \\
\hline & \multicolumn{4}{|c|}{ Expressive writing about cancer-related deep thoughts and emotion } \\
\hline \multirow{2}{*}{ Goal } & \multicolumn{4}{|c|}{ 1. Search, recognize, and accept a cancer-related emotion of oneself } \\
\hline & \multicolumn{4}{|c|}{ 2. Express with writing about cancer-related emotion in 20 minutes } \\
\hline & Step & Aim & Activities & Tme \\
\hline & Introduction & - Enhance group dynamics & Introducing oneself & \\
\hline & & - Trust formation within group and instructor & Introducing instructor Share with last week's life & $15 \mathrm{~m}$ \\
\hline & & - Open mind & Talk with one's expectation and fear & \\
\hline & Mind & - Search a cancer-related & Changing perspective with making & \\
\hline & preparation & deep thoughts and emotion & story from pictures & \\
\hline & & - Recognize a cancer-related deep thoughts & Semi-dynamic writing to complete & \\
\hline & & and emotion & the sentence & $20 \mathrm{~m}$ \\
\hline & & - Select the writing theme & Portrait drawing & \\
\hline \multirow[t]{12}{*}{ Contents } & & & Poetry reading & \\
\hline & & & Body meditation and dialogue writing & \\
\hline & & & Writing letter & \\
\hline & Writing & - Confront a cancer-related & Writing during 20 minute & \\
\hline & & deep thoughts and emotion & Nonstop writing & $30 \mathrm{~m}$ \\
\hline & & - Complete the expressive writing & Record impression after writing & \\
\hline & Self-reflection & - Self-insights & Read a one's writing & \\
\hline & & - Distancing between self and emotion & Observed emotional change after writing & $10 \mathrm{~m}$ \\
\hline & Share and set & & Share the feelings & \\
\hline & up plan & - Strengthening one's experience and identity & Share impression after writing & $15 \mathrm{~m}$ \\
\hline & & & Enhancing positive sympathy & 1 \\
\hline & & - Create new image and frame of life & Make a weekly plan & \\
\hline Materials & \multicolumn{4}{|c|}{ Work book, CD player, Music, Pen, File and Paper, Tissue, specific material for each session } \\
\hline Place & \multicolumn{4}{|c|}{ Seminar Room, Calm and comfortable space, Round table setting } \\
\hline
\end{tabular}

글쓰기 활동을 시도하고 추가하여 표현적 글쓰기에 스트레스 사건 과 관련한 깊은 생각과 감정이 충분히 표현되도록 해야 한다. 〈마음 쓰기 교실>은 암 환자의 감정표현 중재방법에 대한 문헌 탐구와 글 쓰기 프로그램 워크샵 참여, 그리고 전문가와 유방암 환우의 자문 을 토대로 표현적 글쓰기 프로그램의 초기 내용을 구성한 후 적용 가능성 연구를 거쳐 구성내용을 수정, 보완한 후 최종 프로그램을 개발하였다.

먼저 대상자가 집중적으로 글을 쓰게 하기 위해서는 글쓰기 전에 암 관련 생각과 감정을 찾고 인식할 수 있는 활동이 필요하였다. 효 과 적 이 고 심 층 적 인 표현 적 글쓰 기 를 위해 Pennebaker(2004/2007) 와 Adams(1998/2006), 그리고 채연숙 (2010)의 글쓰기 워크북의 내용을 토대로 연구자의 한국글쓰기문 학치료연구소의 Pennebaker 글쓰기 워크샵 연수와 15년간 암 환 자 실무를 담당했던 경험을 바탕으로 그림 감상, 노래 듣기, 빠른 글쓰기, 자화상 그리기, 시집 읽기, 몸 명상, 편지쓰기 등을 선택하 였다.
일반적으로 많은 사람들이 글쓰기를 처음 시작할 때를 가장 어려워 한다. 특히 자신의 스트레스 사건을 떠올리며 그와 관련한 생각과 감정을 되살려 글로 표현하는 것은 쉽지 않은 작업인 것이다. 이 장 벽을 깨기 위해 첫 번째 회기에서는 자신의 이야기가 아닌 제 3자 의 이야기로 시작할 수 있도록 그림감상 후 소설쓰기 활동을 선택 하였다. 이와 같이 암 관련 생각과 감정을 이끌어낼 수 있는 활동으 로 구성된 시간을 마음준비단계로 명명하였고, 대상자들은 이 단계 에서 유방암과 관련된 생각과 감정을 쉽게 탐색할 수 있었다.

표현적 글쓰기는 자기표현의 한 수단이기도 하다(Pennebaker, 1997). 그러기에 지극히 개인적인 경험에 대한 표현일지라도 글쓴 후 각자의 소감을 나누면 감정을 언어로 표현하는 효과가 배가될 수 있다. 이를 위해 글쓴 후 소감나누기와 원하는 사람에게는 자신 의 글을 읽을 수 있도록 하였다. 그러나 표현적 글쓰기에 쓴 글 내 용에 대해서는 공감과 지지만 제공할 뿐 다른 피드백은 하지 않도 록 하였다. 표현적 글쓰기 프로그램 중에 암과 관련한 생각과 감정 을 글보다는 말로 나누려는 대상자에게는 말이 아닌 글로 표현하도 
록 유도해야하는 어려움이 있었다.

Pennebaker의 표현적 글쓰기는 그룹 또는 개인적인 적용이 모두 가능하다. 이 중〈마음쓰기 교실〉은 암 환자에게 제공되는 대부분 의 심리사회 중재가 그룹으로 제공되는 것과 그룹 중재에서 더욱 효과적이라는 선행연구의 결과를 토대로 집단 프로그램으로 개발 하였다(김종남, 이란, 2008). 집단 프로그램으로 진행한 선행연구 의 그룹 구성원 상호간의 적극적인 감정표현 유도와 공감, 그리고 그룹원의 지지를 통한 효과를 유도하기 위함이었다.

표현적 글쓰기 중재 프로그램인 〈마음쓰기 교실〉이 집단 심리사회 간호중재라는 점과 국내 암 환자에게 처음으로 시도되는 프로그램 임을 고려하여 Pennebaker가 제시한 4주보다 많은 6회로 구성하 게 되었다.

일반적인 심리사회 중재의 집단크기는 10 명 내외이다. 집단의 크기 가 크면 참여자들의 자기표현 기회가 감소하고 상호 지지의 기회 역시 감소하게 되므로 6-7명 정도의 인원이 바람직 한 것으로 보인 다. 본 프로그램은 개인 내면의 감정이 드러나기 때문에 심리적 방 어벽이 무너져 있는 경우가 발생하기도 한다. 따라서 공감과 인정 으로 상호지지가 충분히 제공되어야 하며 이를 위해서는 적절한 인 원이 중요한 환경적 요인이다.

일반적으로 심리사회 중재 프로그램의 진행자는 프로그램의 타당 성과 효과에 영향을 미치는 주요한 요인이다. 그러나 Pennebaker(2004)는 표현적 글쓰기에 있어서 그룹의 리더는 중요 한 역할을 하지 않으므로 전문 훈련이 필요하지 않다고 말한다. 이 는 표현적 글쓰기가 지극히 개인적인 작업이므로 전문적인 개입이 요구되지 않는다는 이유에서이다. 하지만, 본 연구의 표현적 글쓰 기 프로그램은 암 환자에게 적용하는 것이며, 일반적인 Pennebaker의 표현적 글쓰기와는 달리 5단계의 구조화된 프로그 램으로 재구성하여 개발한 것임으로 대상자에 대한 이해가 필요하 고 그룹진행, 의사소통과 적절한 지지, 공감 등을 사용할 수 있어야 한다.

암 환자를 대상으로 하는 집단 심리사회 중재 프로그램은 암 환자 의 전반적인 문제 및 치료에 따른 정확한 지식과 암 환자의 감정표 현 양상과 특성, 그리고 집단상담의 기본적인 이해가 풍부해야 프 로그램을 보다 원활하게 운영 할 수 있을 것이다. 즉, 암 진단에서 부터의 일련의 과정과 그 과정에서 경험되는 다양한 정서적 변화를 알고 이해하는 중재자가 요구되어진다. 여러 분야의 전문가에 의한 암 환자 심리상담 프로그램이 가능할 것으로 사료된다. 본 프로그 램은 암 환자의 심리사회적 간호중재에 관심 있는 종양 전문간호사 가 그룹의 리더로 진행할 수 있는 암 환자 집단 심리중재 프로그램
의 하나로 개발하였다.

\section{REFERENCES}

1. 강상건 (2002). 기능성 소화불량증 환자의 분노, 감정표현불능증과 우울, 가정의학회지, 23 (7), 881-889.

2. 김은심, 이민규, 최지명 (2006). 암 환자의 성격특성과 분노표현. 한국 심리학회 논문집, 238-239.

3. 김종남, 이란 (2008). 암 환자를 위한 심리사회적 개입 연구의 개관. 한국심리학회지: 건강, 13(2), 329-357.

4. 김희정, 권정혜, 김종남, 이란, 이건숙 (2008). 유방암 생존자의 외상 후성장 관련요인 탐색. 한국심리학회지:건강, 13(3), 781-799.

5. 배선희 (2009). 암환자의 분노에 대한 문화기술지. 경희대학교 대학 원 박사학위 논문. 서울.

6. 서경현, 김명석 (2003). 암 환자와 정상인의 적대감과 분노 및 죄책감 의 탐색적 비교연구. 한국정신과학학회지, 7(2), 69-79.

7. 신현균, 원호택 (1997). 한국판 감정표현 불능증 척도 개발 연구. 한국 심리학회지 : 임상, 16(2), 219-231.

8. 원호택 (1999). 스트레스와 심리. In 대한심신스트레스학회(편집). 스 트레스 과학의 이해 (p.46) 서울: 신광출판사.

9. 이명선, 김종흔, 박은영, 김종남, 유은승 (2010). 치료중인 암 환자들 의 심리사회적 어려움에 관한 포커스 그룹 연구. 성인간호학회지, 22(1), 19-30.

10. 이평숙, 손정남, 이용미, 박은영, 박지선 (2005). 암 환자의 지각된 스트레스, 분노표현방식과 우울간의 관계. 대한간호학회지, 35(1), 195205.

11. 전겸구, 김동연 (2000). 정서적 스트레스와 신체적 건강. 난청과 언 어장애, 23(1), 1-24.

12. 조선희, 하양숙 (2006). 치료적 글쓰기가 알코올 의존자 가족의 정신 건강 및 외상 후 스트레스 장애 증상에 미치는 효과: 예비연구. 스트레스 연구, 14(3), 203-210.

13. 채연숙 (2010). 글쓰기치료-이론과 실제. 경북대학교 출판부, 대구.

14. Adams, K. (2006). 저널치료의 실제 (강은주, 이봉희, 이영식 Trans). 서울: 학지사. (Original work published 1998).

15. Davidson, K., Schwatz, A. R., Sheffield, D., Moord, R. S., Lepore, S. J., \& Gerin, W. (2003). Expressive writing and blood pressure. In: S. J. Lepore \& J. Smyth(Eds.). The writing cure(pp.17-30). Washington DC: American Psychological Association.

16. Dibbell-Hope, S. (2000). The use of dance/movement therapy in psychological adaptation to breast cancer. The Art in Psychotherapy, 27(1), 51-68.

17. Golden-Kreutz, D. M., Thornton, L. M., Gregorio, S. W., Frierson, G. M., Jim, H. S., Carpenter, K. M., Shelby, R. A., \& Anderson, B. L. (2005). Traumatic stress, perceived global stress, and life events: Prospectively predicting quality of life in breast cancer patients. Health Psychology, 24(3), 288-296.

18. Grassi, L., \& Travado, L. (2008). The role of psychosocial oncology in cancer care. In 
M. P. Coleman, D. Alexe, T. Albreht \& M. Mckee (Eds.). Responding to the challenge of cancer in Europe (pp.219-229). Republic of Slovenia: Tiskarna Radovljica.

19. Ho. R. T. H., Chan, C. L. W., \& Ho, S. M. Y. (2004). Emotional control in Chinese female cancer survivors. Psycho-Oncology, 13, 808-817.

20. Iwamitsu, Y., Shimoda, K., Abe, H., Tani, T., Okawa, M., \& Buck, R. (2005). The relation between negative emotional suppression and emotional distress in breast cancer diagnosis and treatment. Health Communication, 18(3), 201-215.

21. Laccetti, M. (2007). Expressive writing in women with advanced breast cancer. Oncology Nursing Forum, 34(5), 10191024.

22. Lange, A., Rietdijk, D., Hudcovicova, M., Van de Ven, J. P., Schrieken, S., \& Emmelkamp, P. M. G. (2003). A controlled randomized trial of the standadized treatment of posttraumatic stress through the Internet. Journal of Consulting and Clinical Psychology, 71, 901-909.

23. Lazarus, R. S. (1999). Stress and emotion, A new synthesis. London: Springer.

24. Makabe, R., \& Hull, M. (2000). Components of social support among Japanese women

25. with breast cancer. Oncology Nursing Forum, 27(9), 13811390.

26. Mystakidou, K., Tsilika, E., Parpa, E., Kyriakopoulos, D., Malamos, N., \& Damigos, D. (2008). Personal growth and psychological distress in advanced breast cancer. The Breast, 17, 382-386.

27. Olofsson, A., \& Fossum, B. (2009). Perspectives on music therapy in adult cancer care: A hermeneutic study. Oncology Nursing Forum, 36(4), E223-231.

28. Pedersen AF., \& Zachariae R. (2009), Cancer, acute stress disorder, and repressive coping. Scadinavian Journal of Psychology, Early review, published Online Aug. 11.

29. Pennebaker J. W. (1997), Writing about emotional experiences as a therapeutic process. Psychological Science, 8(3), 162-166.

30. Pennebaker J. W. (2004). Theories, therapies, and taxpayers: On the complexities of the expressive writing paradigm. Clinical Psychology: Science and Practice, 11(2), 138-142.

31. Pennebaker J. W (2007). 글쓰기 치료(이봉희, Trans), 서울: 학지 사. (Original work published 2004).

32. Rancour, P., \& Brauer, K. (2003). Use of letter writing as a means of integrating an altered body image : A case study. Oncology Nursing Forum, 30(5), 841-846.

33. Servaes, P., Vingerhoets, M., \& Vreuhdenhil, G. (1999). Inhibition of emotional expression in breast cancer patients. Behavioral Medicine, 25(1), 23-27.

34. Smith, S., Anderson-Hanley, C., Langrock, A., \& Compas, B. (2005). The effects of journaling for women with newly diagnosed breast cancer. Psycho-Oncology, 14, 1075-1082.

35. Spigel, D., \& Giese-Davis, J. (2003). Depression and cancer: Mechanisms and disease progression. Biological Psychiatry, 54, 269-282.

36. Stanton, A., Danoff-Burg, S., Cameron, C., Bishop, M., Collins, C., Kirt, S., Sworowski, L., \& Twillman, R. (2000). Emotionally expressive coping predicts psychological and physical adjustment to breast cancer. Journal of Consulting and Clinical Psychology, 68(5), 875-882.

37. Stanton, A., Danoff-Burg, S., Sworowski, L., Collins, C., Branstetter, A., Rodriguez -Hanley, A., Kirk, S., \& Austenfeld, J. (2002). Randomized, Controlled trial of written emotional expression and benefit finding in breast cancer patients. Journal of Clinical Oncology, 20(20), 4160-4168.

38. Temoshok, L. R. (1995). On biobehavioral models of cancer stress and disease course. American Psychologist, 50(12), 11041105.

39. Zakowski, S. G., Ramati, A., Morton, C., \& Johnson, P. (2004). Written emotional disclosure buffers the effects of social constrains on distress among cancer patients. Health Psychology, 23(6), 555-563. 